「機械分子エ 学」のこと*

小 竹

進*1

\title{
On the "Molecular Mechanical Engineering"
}

\author{
Susumu KOTAKE
}

Key Words: Mechanical Engineering, Molecular Enginnring, Molecular Mechanics

\section{1.「機械分子工学」ことはじめ}

「機械分子厅学」という学部での講義を始めて 5 年 になる。问転温度だとかクラスタだとかいう菩葉が学 生たちの川们自然にでてくるのを耳にするとうれし くなるが, 何となく当然のような気もする. 5 年前, 機 械系の学生には少し奇異に感じられたかもしれない が，思いきって分子原子レベルでのマクロな現象の理 解を試みた．奇異に感じたのは学生のほうでなくて先 生のほうかもしれない，柔らかい頭の学生たちは既成 の知識がないからどのようにも対処できるが，先生の ほうは既成の知識と予盾なくなどと気を遣うから大変 である.ふく射などの量子力学から熱伝導, 粘性, 応力 などを, ミクロからマクロ, マクロからミクロに現象 をとらえ理解することは, 頭の固い先生よりも結構自 由自在にやっている。

半導体などの材料の製造や真空技術などの進歩のた めに，分子原子レベルで現象を理解しなければならな いことが多くなってきたことも事実であるが,熱流体 工学や材料工学においてもマクロなことが一応わかっ てしまうとその先はどうなっているのかということに なるのは人情でもあろう。例えば，沸騰や凝縮という 現象では，最初に沸騰や凝縮の核ができるという前提 でそれから先のことはだいたい理解が終わっていろ いろな利用や忍用が行われている。そこまで行くと， それではそういう核とはどんなものか，どのようにし てできるのかということになるのは当然である。マク ロマシン,ナノマシンといっているが, その空気中で

* 原稿受付 平成 5 年 12 月 14 日。

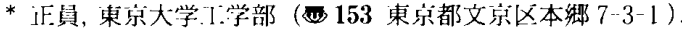

の環境はもはや連続体としては扱えない領域にあり， それが動くときに働く抵抗などの動的な特性の評価は 今までの連続流体力学の廷長ではできない，薄膜技術 も急激な進歩をとげているが，その物性值などはどう なっているのであろうか. 熱伝導はよくなるのか悪く なるのか. ナノ加工というとき何をどのくらいの精度 でどう加工するのか.こうした領域では，今までの連 続体としての熱流束とか圧力, 応力・ひずみという概 念は再検討しなければならない。

こうした機械工学の現状では，そこで扱われる現象 や技術をもっと分子原子のレベルで理解する必要があ るし，多くの場合はそのほうが理解しやすい。このよ うにして始まった話が「機械分子工学」である。もち ろん,このような言葉は今まで聞いたこともないが, 重要なのは「機械」であり，「分子」であり，「工学」 であることである。

\section{2.「機械」であり，「分子」であり， 「エ学」であること}

平成 6 年度の文部省科学研究費補助金申請で, 重点 的な格段の発展を目的とする重点研究領域研究 (計画 研究)の課題をみると,「分子」と名のつくものは 83 課 題のうち 32 課題もある(研究項目を含む)。 まさに「分 子」ばやりである. 分子原子レベルでの現象の理解は それ自身として新しいことではないが, 計測技術が大 きく進歩したことと計算機の発達により大容量高速な 計算が可能になったことにより，さらに新しい進展を 期待しようということである。こうした物理・化学の 「分子原子」がわかっていれば，なにも機械の「分子原 子」など必要ないのではないかと思われるかもしれな いし，そういう人もいる。しかし，それは「機械」のこ 
とをよく知らない人のいうことである.

\section{(1)「機械」であること}

「機械」であつかうエネルギー，寸なわち，材料加工， 流体運動, 熱变換輸送などであつかうエネルギーは, 化学反応など化学分野であつかうエネルギーに比べる とオーダが 2 〜 けた小さく，化学エネルギーなどで はその残りかすである。しかし，機械技術者はこれら の弱いエネルギーを巧みに操作して，物を作ったり動 かしたりしている．しかもこのころは少しでも有效に ということで，その弱いエネルギーを精度よく制御し て, 0. ?\%という効率や性能の向.上を問題にしてい る. 化学エネルギーなどからみれば誤差の詥差範网の 話である。したがって,「機械」に扔ける分子原子の問 題もこうしたエネルギー範囲のものでなければならな い. 光のエネルギーでいうと可視光レベル以下の問題 である. 問題によっては, 鉄の溶解などのように物質 の色が変わることがあるが，工作や流れの問題ではほ とんど色が変わらない範囲の問題である. エネルギー が高い場合でもせいぜい燃焼現象であり，ここでも材 料の問題で取扱う最高温度には制限がある。こうした 弱いエネルギーを取扱うためには, より強いエネルギ ーレベルからみると誤差範国のレベルの精度での制御 が必要であり, 上り高度な理解と制御技術が要求され る.

分子の運動は分子内の電子や原子核の電荷分布に基 づくクーロン力による。この電荷分布が静的に正ある いは負に片寄っているときは,この力は強い力にな る.しかし，電荷分布が静的に片寄っていないときで も, 分子原子の運動により動的に片寄りが生じて結果 として分子間に力が働く、これがファンデルワールス 力である.したがって, この力は分子内の電子の軌道 のひずみにより生じるもので, 電子軌道が大きく変化 する化学結合の力に比べると非常に弱いものである。 しかし，これはすべての分子の間に働くことになる。

「機械」の現象ではこのファンデルワールスカが主力で あり、このような弱い力を相手にしなければならな い.そのためには特別の創意と精度よい取扱いが必要 なのである.

こうした分子原子間の力(ポテンシャル)はシュレー ディンガー式を解くことによってもとめられるが, 計 算機の発達によって化学エネルギーのレベルではプロ グラムがコード化されており，容易に計算できる。簡 単な分子であればシュレーディンガー式など知らなく てもその解がもとまり，そのエネルギー状態を知るこ とができる。しかし，「機械」レバルの分子すなおちフ アンデルワールスカをもとめようとすると，簡単では
なく、この計算コードは単なる䛊差しか子年えない。こ の弱い分子間力をもとめるためには 2 けたあるいは 3 けたも精度のよい式の解法を見つけなければならない のである。そして，それ柿「機械」の問題として解決し なければならないのである。なぜなら，そのような工 ネルギーが必要なのは「機械」だからである。

(2)「分子小であること

ト述の「機械」エネルギーレベルでは, 原子状態その ものが問題になるより分子状態抢よびその運動が問題 である、この分子の状態捛よびその運動とともに分子 集団としての状態と運動が問題にされ, そしてマクロ につながらなければならない。電子や原子状態がそれ 自身問題になることもあるが，それも分子状態の特殊 な場合として理解できる。この点で,「機械原子丁学」, 「機械量子エ学」というのは意味がない，原子も量子も すべてより複雑な「分子小のなかに含まれてしまうと 间時に、「機械」というマク口な状態には「分子小でし かつながらないからである。光の吸仪や金属の熱伝導 では, 電子の荲子的状態や運動が問題になるが, そこ でもそれ自体が閣題になるというより，分子原子打よ びその集合体とのかかわりにおいての䦤題が重要であ る.

温度や压力という概念牥，もっとも公く用いられて いるが，物筫の状態量の…つととしての熱力学的な意味 が強い。熱力学という理諭体系はこうした物所の状態 量をa prioriに「始めに…ありき」そして「これらは… を満足するあるいは満是しなければならない」という ことから出発する，そこではなぜそういう状態革があ り，それらがなぜそのような法則を満足しなければな らないかの説明はない。・.つつの)公理をもとにきれいに 理論体系を組みトげている数学のようなものであり， それに物理的解釈をつけるのは相当の経験が必要であ る。その上うな経験の怪しい先生がまつたく経験のな い学生にこれらの理論を教えるのは, 論理体系がすつ きりしているだけに非常に容易ではあるが単なる数学 の閧にすぎない。そのような理論に，学生が自分の 身近な自然現象の理解や工学的な道具としての興味を しめきないことは当然である。流体力学や材料力学は 力学という動的な要素が入るりで熱力学肪どではない かもしれないが事情はほとんど同じである。流体は流 れる、物体はひずむということから始めている。なぜ 流れるのか、なぜひずむのかということの説明はな い。穵こでは a priori に速度があり，力がある。速度や カ啶義はない. H常霄語として, 速度とか力という 概念がなんとかあるから，そこから出発してもそれ以 後の論理の発展についていけるが、あやふやにしても 
そのような概念がないときには大きな支障をきたす。 エントロピーなどその典型であり，定義は a priori で あり, 理解は多くの経験を積んでからという a posteriori 的なものである.

そこで，「分子」であることの必要性がでてくる．分 子原子の系の理解は簡単である.その状態や運動は非 常に複雑であり, 熱力学になったり, 流体力学や材料 力学になったりするが, 基本的には分子原子の集まり である。その状態においてこうした複雑さの基本をは つきりさせておこうということである。すなわち，温 度とは分子原子のもつ運動エネルギーである。分子は この運動エネルギーのほかに分子間の力のもとになる ポテンシャルエネルギーをもつから，これらの和が分 子のエネルギーであり，分子集団としては内部エネル ギーとなる。流体の速度とは分子の集団としての平均 速度である。代力とは分子集団に働くそれ以外の分子 からの才の头均である。エントロピーとは分子系が取 り得る状態の総和である..$\cdots \cdots$, などである。すべて を分子の状態とその運動として理解する。基本の理解 とそれからの論理展開には経験はいらない.しかし， その結果の理解・解釈には経験が必要であり，それが 既存のマクロな知識とのつながりである. 分子の運動 エネルギーを吣に発展するものは熱力学(エネルギ 一方程式)に，集団としての運動を問題にするときに は流体力学(運動方程式)に，集団としての分子の力の 関係を問題にするときには材料力学(状態方程式)にと 発展する(汹 1 )。そそ発展は演えき的であり，経験の ない者にもおかりやすいし，経験のある者には新しい 発見がある。

(3)「「学」であること

「科学〕が自然現象の因果関係やそこに存在寸る法

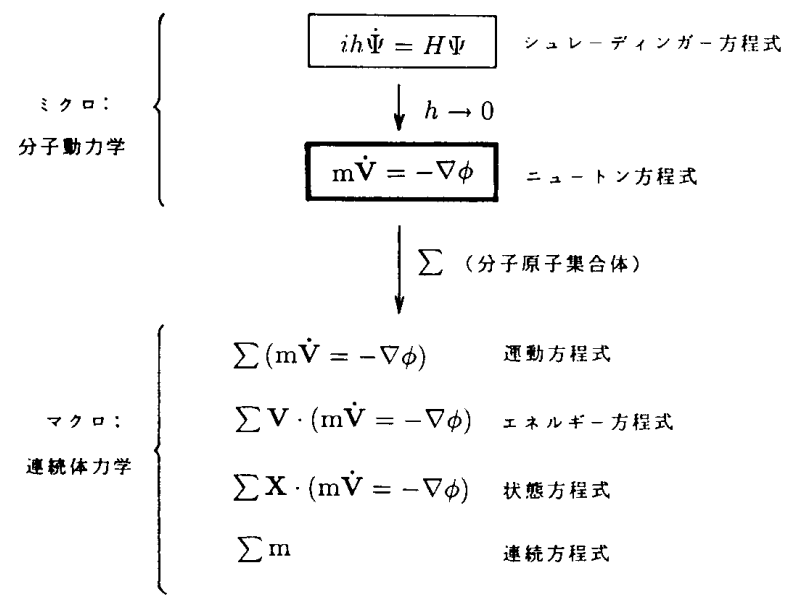

虲 1 分子動少学と連続体力学 $(H:$ ハミルトニアン, $\Psi:$ 波動関数, $\phi:$ ポテンシャル, $m:$ 質㫣, $V:$ 速度, $x:$ 位罱
則性を解明するというやや趣味的であるのに対して， 「丁学」はそうした結果やその過程を利用・応用して広 い意味の生産をするという目的指向である，後者の中 心は，自然現象の法則性を忍用利用して何かを生産す る，すなわち何かをつくる，まとめることにある。「科 学」が部分的であるのに対して「工学」は全体的でな ければならない.「工学」では, 部分的に優れていても 全体的な調和がとれていなけれげ意味をなさない，何 かをまとめなければならないということで，「工学」は しぱしば部分を犠性にしているが,より高性能高効率 性を問題にするためには部分と全体の調和が必要であ る.そこには“美”がなければならない.「工学」では， 部分が全体としてのシステムでどう機能するかがつね に問題になる．部分から全体，ミクロからマクロだけ では「土学」は成り立たないのであり，つねに全体から 部分, マクロからミクロをみなければならないのであ る.ここに「学」の複雑さと面白さがある，機械分 子「「工学」でなければならない理由がある。機械分子 浮はつ权にミクロからマクロ, マクロからミクロと つながらなければならない。

\section{3. ミクロからマクロ, マクロからミクロ}

分子原子の状態・運動の単純な系として出発して, 連続体力学につなぐというミクロ 連続体力学から分子原子の状態や連動を演えきするマ クロ $\rightarrow$ ミロの関係は可逆でない.分子原子系を固定 してその状態・運動を見る目 (時間的空間的スケール) を大きくしていくと，目の大きさによって写る像は異 なるかもしれないが,一つのマクロにつながる.これ が前者である。後者ではまず大きな目で見た像を固定 する、したがって大きな目では同じ見えても小さな月 で見ると大きく異なっていることが考えられ，同じミ クロ系に行き着くとは限らない. 同じマクロ現象でも どのミクロな系によるのかということはわからない. それがわかる法則が見つかるまでは，いろいろな経験 が必要となる。

分子間力を含めて, 分子原子の状態はシュレーディ ンガー式からもとめられるが, この式から分子原子系 の運動をもとめるのは谷易でない。もともと, シュレ ーディンガー式が状態のエネルギー遷移関係を記述し て, 分子原子の位置と運動を確定的に表す運動の式で ないことによる。機械丁学であつかうエネルギーレ心゙ ルでは, 多くの場合シュレーディンガー式のエネルギ ーレベルの量子性は平均化 $(<\Psi|V| \Psi\rangle)$ されてなく なり, 分子原子の連動はより確定的になり古典的な質 点の力学(ニュートンの式)で記述される(図 2).これ 


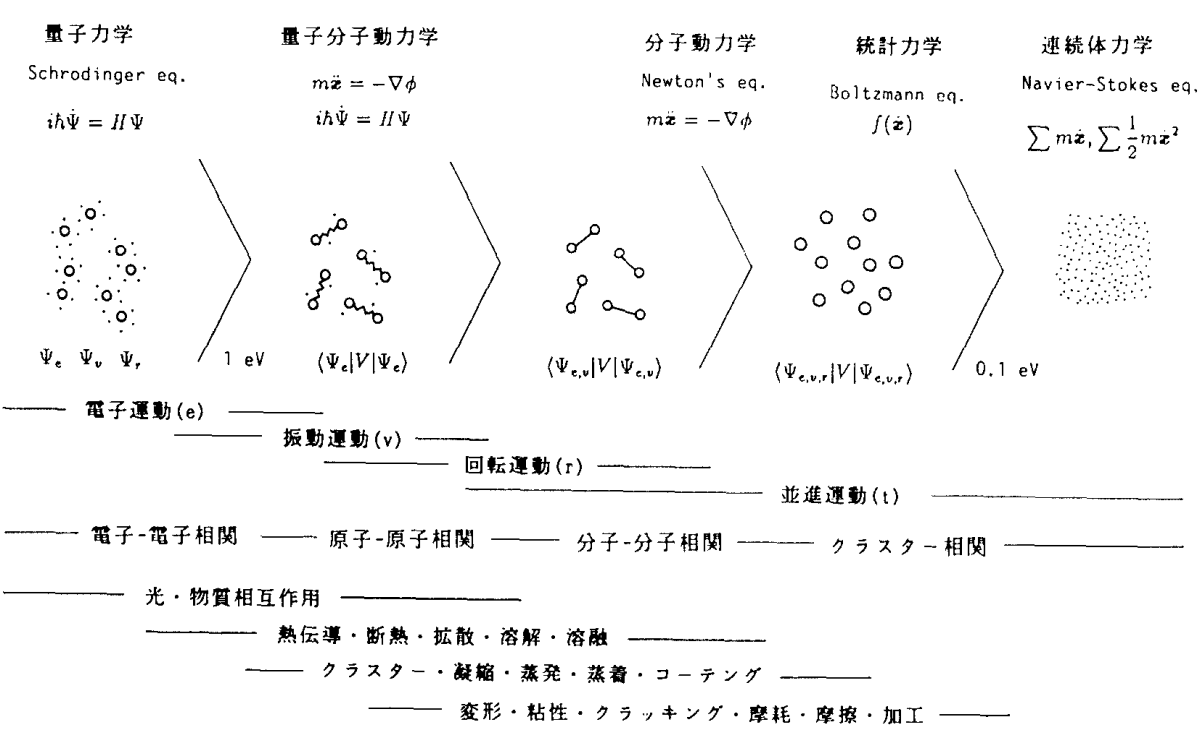

図 2 熱物質伀達におけるミクロニマクロ少学

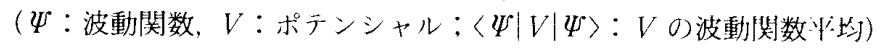

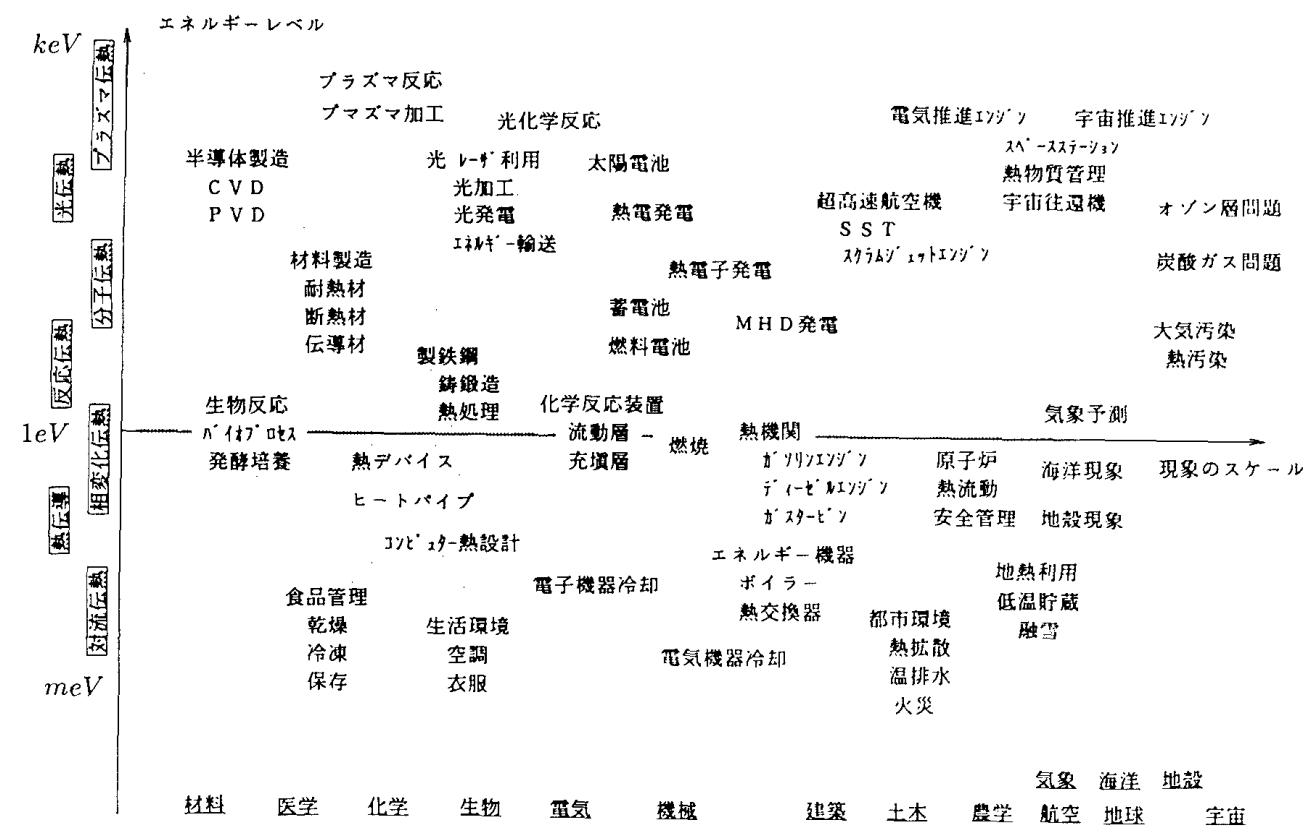

脑 3 「機械分子:学」0分野

を分子動力学という.ただし, 分子間力や光・電子との 干渉はシュレーディンガー式の問題であり，量子分子 動力学として取扱わなければならない. 計算機の発達 と基礎式が簡単なことから分子動力学手法による数值 計算の研究は急増して，なかにはこれでなにかマクロ なことが理解できたといっているものもあるが，そん な簡単なことではない。

たしかに, 分子動力学は分子原子レベルでのミクロ な現象の理解には大きな役割を果たしており，これか らも大きな威力を発するであろう。しかし，マクロな
現象はそれほど演えき的でないということを忘れては ならない，例えば，温度や庄力が一䇥な系という場命 どのようにしてどのように一垃なのかという多様性が あると同時に，それに刘㤁するミク口な系が一元的で あるとは限らないからである。このミクロ系の多様性 と多元性が機械分子:T学の一つの大きな鬽少であり， 末知の分野として将来性が期待される要素である。

\section{4. 機械分子工学のこれから}

機械技術の発達に伴って，機械厂学の基礎となって 
きた a priori な前提をより根本から演えき的に理解す る必要が生じてきたことと,さらにそのほうが理解し やすいということのために，機械分子工学という新し い理論体系の必然性を説明した。それでは，この機械 分子: I学という理論体系が機械技術の発展進歩にどう 結びつくのか，あるいはそれ自身の将来はどうなのか という問題を考えてみたい。

機械亡:学という幅広い:I学分野と分子工学あるいは 分子科学という基礎科学分野を組合せると非常に広い 你野になる(㧚 3 )。縦軸は, 現象に関与寸る分子の工 ネルギーの大きさを表し, 化学反纫(燃焼)のエネルギ 一約 $1 \mathrm{eV}$ を基準にして定性的な大小関係を表してい る. 横軸は現象システムの寸法の大小関係である. 網 掛けの部分は，機械分子「学的な考え方・理解が特に 今後必要とされる領域である。このような分野でミク 口な現象が理解され，いままで行き詰まっていたマク ロな問題が解決されたり, 新たなマクロな問題のブレ ークスルーとなったり, あるいは逆にマクロな問題が 新たなミクロな問題を提供したりということで, 両者 相補して大きく発展するであるうことは確実である。 特に, 今までミク口な立場での現象の理解は大きく遅 れていたので, 当分はこの種の理解がつづくであろう
が, 次にはこれらを利用したマクロの改良やその進展 さらには新しいマクロの発見が続くことが期待され る. 例えば, 薄膜・微粒子・界面での分子原子の運動状 態の理解による熱および物質伝達, 界面力・摩擦・接着 現象などの制御, 個々の分子原子運動の励起や規制制 御によるマクロ物性の制御, 蒸発・凝縮あるいは融解・ 凝固といつた相変化過程の制御あるいはその制御によ る生成物質の組成や物性の制御, さらには, 光との相 互作用を利用して分子原子のエネルギーレベルを変化 させることを組合せるとこうした分野はさらに大きく 広がる。また，もう一つの大きな特長は，これまでは， ものがあって結果がこうなるという消極的であった問 題が,これからは,こうした結果にするためにこうし たものが欲しい，そうした特性(ポテンシャル)をもつ 分子原子を設計してほしいという積極的なことができ るようになることである. 熱伝導に三次元的な異方性 をもつ分子原子はこうでなければならない. 乱流を抑 えるあるいは促進する分子原子はこのようなポテンシ ヤル特性をもてばよいなどということがわかるであろ j.

楽しい機械工学の将来である。 